\title{
Homenagem Póstuma à Professora Doutora Solange Barbosa de Moraes Barros
}

É com muita tristeza que compartilhamos com os leitores da Revista Emancipação o falecimento, no dia 27/10/2017, da Professora Dra Solange Aparecida Barbosa de Moraes Barros. Membro do Conselho Editorial da Revista Emancipação desde 2003.

A Professora Solange foi docente do Departamento de Serviço Social desde 1984 tendo uma carreira de sucesso e bastante fecunda na Universidade Estadual de Ponta Grossa (UEPG). É de reconhecimento notável os relevantes serviços prestados à Comunidade Universitária durante sua vida acadêmica e a cidade de Ponta Grossa enquanto profissional de Serviço Social, dedicando especial atenção humanística a luta docente no ensino público e a implementação de políticas públicas, nas áreas da saúde, criança e adolescência.

A sua história na instituição se fez como professora no Curso de Serviço Social e no Programa de Pós-Graduação em Ciências Sociais Aplicadas (mestrado e doutorado). Foi coordenadora do Núcleo de Estudos, Pesquisa e Assessoria na Área da Infância e da Adolescência e Juventude (NEPIA). Foi membro efetivo do Conselho Editorial das Revistas: Emancipação e Conexão da UEPG e Capital Científico da Unicentro (Universidade Estadual do Centro-Oeste). Atuou na coordenação do Mestrado em Ciências Sociais Aplicadas da UEPG (2008-2011); na coordenação Pedagógica da Residência em Gestão Pública - Governo do Paraná (2013-2015); e na coordenação do curso de especialização Gestão em Saúde - Capes (Coordenação de Pessoal de Nível Superior)/EaD (Educação a Distância)" (UEPG, 2017).

Solange foi ainda Secretária Municipal de Assistência Social de 2001 a 2003. Neste período assumiu a Presidência da Fundação Municipal do Idoso e da Pessoa com deficiência. Participou em conselhos, comissões e consultoria em âmbito municipal e estadual. Atuou na defesa de direitos da criança e adolescência e da saúde. Primou pela dimensão ética/política na ampliação de espaços para o Serviço Social.

Amiga e companheira de todas as horas, o seu caminho na Instituição, ficou registrado pelos seus dotes de amizade, educação e amor pelo ensino, enfatizando sempre a importância do conhecimento como o mais valioso patrimônio de um povo. Sem sombra de dúvidas, a professora Solange soube conquistar o respeito e admiração de todos: alunos, professores e agentes universitários desta Universidade.

Nos deixa o sentimento do dever cumprido.

Gisele Alves de Sá Quimelle Lenir Ap. Mainardes da Silva Sandra Maria Sheffer 